Quebec Cooperative Study

of Friedreich's Ataxia

\title{
Brain Neurotransmitter Receptors in Friedreich's Ataxia
}

\author{
I. D. REISINE, J.AZARI, P.C.IOHNSON, A. BARBEAU, R. HUXTABLE AND H.I. YAMAMURA
}

SUMMARY: The hinding of ' $H$-quinuclicliml henzilate. a muscarinic cholinergic antagonist. of 'H-dihydroalprenolol, a hela adrenergic antagonist, and of ${ }^{3} \mathrm{H}$ flunitrazepam, a ligand which lahels henzodiazepine receptors, was examined in se'veral regions of control and Friedreich's ataxia $(F . A)$ brains. ${ }^{3} \mathrm{H}$-Quinuclidim.l hen=ilate hinding appeared to increase in the inferior olivory nucleus, anterior and posterior cerehellar vermi hut was unaltered in the dentate nucleus and cerehellar hemisphere of F.A hrain. The hinding of

RÉSUMÉ: Nous avons examiné clans plusieurs régions de cerveaux contrôles et provenant d'ataxie de Friedreich $(A F)$ la liaison de plusieurs ligand.: ${ }^{3} \mathrm{H}$-quinuclidinyl henzilate $(Q N B)$, un antagoniste chlorinergique muscarinique: ${ }^{3} \mathrm{H}$-dihydroalprenolol (DHA), un antagoniste $\beta$ adrénergique; 'H-flunitrazepam (FLU). un ligand qui marque les récepteurs à la benzodiazepine. La liaison de QNB semble augmentée dans le noyau olivaire inférieur. le vermis céréhelleux antérieur et
'H-dihydroalprenolol seemed to increase in the inferior olivary nucleus yet was not different from controls in the dentate mucleus, cerehellar hemisphere, anterior and posterior cerehellar vermi of $F A$ hrains. ${ }^{3} \mathrm{H}$-Flunitrazepam binding was slightly lowered in the inferior olivary and dentate nuclei hut was unchanged in the other FA hrain regions examined. The present study suggests possible trends in neurotransmitter receptor alterations in post-mortem hrain tissue of FA patients.

postérieur, mais est inchangée clans le noyau dentelé et les hémisphères céréhelleuses de cerveaux $A F$. La liaison du DHA semble également augmenté dans le noyau olivaire inférieur, mais ne diffère pas des contrôles dans le nolau dentelé, les hémisphères céréhelleuses et le vermis antérieur et postérieur. Par contre la liaison FLU élait légèrement diminuée dans les nolaux olivaires inférieurs et dentelés mais était intacte dans les autres régions examinées de cerveaux $A F$.
From Departments of Pharmacology and Pathology, College of Medicine, University of Arizona Health Sciences Center. Tucson and the Department of Neurobiology, Clinical Research Institute of Montreal.

Reprint requests for the complete supplement on Friedreich's ataxia (Phase Two, Part Two) to:

Dr. André Barbeau, M.D., Clinical Research Institute of Montreal, 110 Pine Avenue West, Montreal, Quebec, Canada H2W IR7.

\section{INTRODUCTION}

Friedreich's ataxia (FA) is an inherited neurological disorder that was first described in 1861 (Fried reich, 1861). Neuropathological studies have revealed that there is severe neuronal degeneration in several regions of the central nervous system. In particular, the sensory fibers of the posterior columns, the spinocerebellar and corticospinal tracts, the brainstem, and cerebellum are most affected in the disease (Wintrobe et al., 1974).

At present, little information is available concerning the possible neurochemical alterations that might be present in the FA central nervous system. Previous studies on such neurological disorders as Parkinson's disease and Huntington's chorea have revealed much information concerning the neurochemical abnormalities of these degenerative diseases (Reisine et al., 1977; Yamamura, 1978). Thus, in a recent study by Huxtable et al., (1978), marked changes in the levels of several amino acids were observed in various FA brain regions which upon pathological examination exhibited extensive neuronal destruction. In the present study, using a limited number of brain samples, we report on the density of muscarinic cholinergic, $\beta$ adrenergic, and benzodiazepine receptors in brains obtained postmortem from two subjects diagnosed as having FA as compared to four patients devoid of any neurological disorders.

\section{SUBJECTS AND METHODS}

Post-mortem brain tissue from two patients (average age 19 years) diagnosed as having Friedreich's ataxia were used in this study (Table 1). Four brains were obtained postmortem from individuals (average 
age 40.5 years) devoid of any neurological or psychiatric disorders. The onset ( 5 years old) of ataxia and death (19 years old) in both FA patients was early in life. Pathological examination of the brain and spinal cord of both FA patients revealed degeneration of the posterior columns, pyramidal and spinocerebellar tracts. Each FA patient had distal peripheral neuropathy with kyphoscoliosis and pes cavus. Both patients had cardiomyopathy.

Attempts were made to obtain age matched controls for this study. Two of the controls patients were between 20-30 years old at the time of death (Table 1). Two older patients were included in the control group since no apparent differences were noted in neurotransmitter receptor binding in the older patient's brain tissue as compared to binding in brain tissue from the younger control patients. Thus, although age matched controls were not used in this study, no significant differences in receptor binding characteristics were observed with age. Therefore, any differences in receptor binding between the FA and control groups is not the result of differences in the ages of the patients at the time of death.

On the average, five hours elapsed between the time of death and freezing $\left(-80^{\circ} \mathrm{C}\right)$ of the brain tissue. Before freezing the tissue, the inferior olivary and dentate nuclei, anterior and posterior cerebellar vermi, and cerebellar hemisphere were dissected from each brain. On the day of the

TABLE 2

Regional ${ }^{3} \mathrm{H}-\mathrm{QNB}$ Binding in FA and Normal Brains

\begin{tabular}{l|ccccc}
\hline & \multicolumn{3}{|c}{ Brain Region } \\
Brain Number & $\begin{array}{c}\text { Inferior } \\
\text { Olivary } \\
\text { Nucleus }\end{array}$ & $\begin{array}{c}\text { Dentate } \\
\text { Nucleus }\end{array}$ & $\begin{array}{c}\text { Ant. Cere. } \\
\text { Vermis }\end{array}$ & $\begin{array}{c}\text { Post. Cere. } \\
\text { Vermis }\end{array}$ & $\begin{array}{c}\text { Cere. } \\
\text { Hemisphere }\end{array}$ \\
\hline FA & & & & & \\
A-77-178 & 23.8 & 37.0 & 48.2 & 52.2 & 47.9 \\
A-77-218 & 40.3 & 18.9 & 57.2 & 59.6 & 48.3 \\
Average & 32.1 & 28.0 & 52.7 & 55.4 & 48.1 \\
Normal & & & & & \\
A-77-101 & - & 28.8 & 31.1 & 34.2 & 45.2 \\
A-77-71 & 15.6 & 31.8 & 40.7 & 33.7 & 50.1 \\
A-77-51 & 23.2 & - & 26.1 & 31.0 & 61.1 \\
A-75-144 & - & 19.2 & 24.6 & 38.5 & 52.3 \\
Average & 19.2 & 26.6 & 30.6 & 34.3 & 52.2 \\
\hline
\end{tabular}

The values are expressed as fmole of ${ }^{3} \mathrm{H}-\mathrm{QNB}$ bound per $\mathrm{mg}$ protein.

The concentration of ${ }^{\prime} \mathrm{H}-\mathrm{QNB}$ used was $100 \mathrm{pM}$

experiment, the tissue from each brain region (about $50 \mathrm{mg}$ ) was thawed and then homogenized with a Polytron homogenizer (Brinkman, setting 5 for $30 \mathrm{sec}$.) to make a $5 \%$ homogenate in $50 \mathrm{mM}$ sodium-potassium phosphate buffer ( $\mathrm{pH}$ 7.4). The tissue was washed once by diluting it with $15 \mathrm{ml}$ of buffer and centrifuging it at $48,000 \times \mathrm{g}$ for 15 minutes in a Sorvall RC2-B centrifuge. The pellets were resuspended in buffer to make a $5 \%$ homogenate. Protein determinations were performed by the method of Lowry et al., (1951).

The ligands employed to measure the various receptor levels were as follows: cholinergic muscarinic receptor, ${ }^{3} \mathrm{H}$-quinuclidinyl benzilate

TABLE 1

Description of patients from which post-mortem brain tissue was obtained

\begin{tabular}{cccc}
\hline Brain Number & $\begin{array}{c}\text { Interval between } \\
\text { Death and freezing } \\
\text { (hrs.) }\end{array}$ & $\begin{array}{c}\text { Patient } \\
\text { Age } \\
\text { (yrs.) }\end{array}$ \\
\hline
\end{tabular}

FA

\begin{tabular}{lccl} 
A77-178 & 3.5 & 19 & Heart Failure due to Cardiomyopathy \\
A77-218 & 5.5 & 19 & Pneumonia \\
Average & 4.5 & 19 & \\
Normal & & & \\
A77-101 & 3.0 & 21 & Respiratory Failure \\
A77-71 & 9.0 & 27 & Lymphoma \\
A77-51 & 2.0 & 63 & Liver cirrhosis \\
A75-149 & 5.0 & 51 & Peritonitis \\
Average & 5.0 & 41 & \\
\hline
\end{tabular}

( $\left.{ }^{3} \mathrm{H}-\mathrm{QNB}\right) ; \beta$-adrenergic receptor, ${ }^{3} \mathrm{H}$ dihydroalprenolol ( $\left.{ }^{3} \mathrm{H}-\mathrm{DHA}\right)$; and the benzodiazepine receptor, ${ }^{3} \mathrm{H}$-flunitrazepam $\left({ }^{3} \mathrm{H}-\mathrm{Flu}\right)$. The interaction of these ligands with their respective receptors has been described elsewhere (Yamamura and Snyder, 1974; Bylund and Snyder; 1976; Speth et al., 1978).

Briefly, the muscarinic cholinergic receptor was assayed in tissue homogenates (50-100 $\mu \mathrm{g}$ protein) which were incubated in $2 \mathrm{ml}$ of 50 $\mathrm{mM}$ sodium-potassium phosphate buffer (pH 7.4) for 60 minutes with 100 pM ${ }^{3} \mathrm{H}-\mathrm{QNB}(29.4 \mathrm{Ci} / \mathrm{mmole})$ in the presence and absence of $1 \mu \mathrm{M}$ atropine. The reaction was terminated by vacuum filtration through $\mathrm{GF} / \mathrm{B}$ glass fiber filters, followed by four $5 \mathrm{ml}$ rinses of ice cold buffer. Bound ${ }^{3} \mathrm{H}$ QNB retained on the filter was extracted in $9 \mathrm{ml}$ of a toluene based scintillation cocktail and radioactivity was monitored in a Searle Mark IIII liquid scintillation counter. The amount of isotope displaced by atropine is termed specifically bound $\mathrm{QNB}$ and is a measure of the number of receptor sites present.

The benzodiazepine receptor was assayed in tissue homogenates (50-100 $\mu \mathrm{g}$ protein) which were incubated for 90 minutes at $0^{\circ} \mathrm{C}$ in $2 \mathrm{ml}$ of buffer containing $0.5 \quad \mathrm{nM}{ }^{3} \mathrm{H}-\mathrm{Flu} \quad 87.5$ $\mathrm{Ci} / \mathrm{mmole}$ ) in the presence and absence of $1 \mu \mathrm{M}$ clonazepam. Termination of the reaction was similar to that 
TABLE 3

Regional ${ }^{3} \mathrm{H}$-Flunitrazepam Binding in FA and Normal Brains

\begin{tabular}{l|ccccc}
\hline & \multicolumn{5}{|c}{ Brain Region } \\
Brain Number & $\begin{array}{c}\text { Inferior } \\
\text { Olivary } \\
\text { Nucleus }\end{array}$ & $\begin{array}{c}\text { Dentate } \\
\text { Nucleus }\end{array}$ & $\begin{array}{c}\text { Ant. Cere. } \\
\text { Vermis }\end{array}$ & $\begin{array}{c}\text { Post. Cere. } \\
\text { Vermis }\end{array}$ & $\begin{array}{c}\text { Cere. } \\
\text { Hemisphere }\end{array}$ \\
\hline FA & & & & & \\
A-77-178 & 1.9 & 1.9 & 58.8 & 53.2 & 55.4 \\
A-77-218 & 5.4 & 5.6 & 42.8 & 41.1 & 53.7 \\
Average & 3.6 & 3.7 & 50.8 & 47.2 & 54.6 \\
Normal & & & & & \\
A-77-101 & - & 4.2 & 31.4 & 28.6 & 28.1 \\
A-77-71 & 9.0 & 7.3 & 56.5 & 35.2 & 51.4 \\
A-77-51 & 5.8 & - & 52.4 & 54.2 & 54.8 \\
A-75-149 & - & 8.1 & 60.4 & 50.6 & 78.3 \\
Average & 7.4 & 6.5 & 50.2 & 42.2 & 53.2 \\
\hline
\end{tabular}

The values are expressed as fmole of ${ }^{3} \mathrm{H}$-Flu bound per $\mathrm{mg}$ protein.

The concentration of ${ }^{3} \mathrm{H}$-Flunitrazepam used was $500 \mathrm{pM}$. described above. Specific ${ }^{3} \mathrm{H}-\mathrm{Flu}$ binding was defined as that binding displaceable by $1 \mu \mathrm{M}$ clonazepam.

The $\beta$-adrenergic receptor was assayed in tissue homogenates $(300 \mu \mathrm{g}$ protein) which were incubated for 30 minutes at $25^{\circ} \mathrm{C}$ in $2 \mathrm{ml}$ of sodiumpotassium phosphate buffer containing $0.25 \mathrm{nM}{ }^{3} \mathrm{H}-\mathrm{DHA}(58 \mathrm{Ci} / \mathrm{mmole})$ in the presence and absence of $0.1 \mu \mathrm{M}$ (-)-propranolol. Termination of the reaction was similar to the previously described assays except that the filters were rinsed with buffer maintained at $25^{\circ} \mathrm{C}$. Specific ${ }^{3} \mathrm{H}-\mathrm{DHA}$ binding was defined as that binding displaceable by $0.1 \mu \mathrm{M}(-)$-propranolol.

\section{RESULTS}

The results of this study reveal that there may be an increase in ${ }^{3} \mathrm{H}-\mathrm{QNB}$ binding in the inferior olivary nucleus and in the anterior and posterior cerebellar vermi of FA brains (Table 2). ${ }^{3} \mathrm{H}-\mathrm{QNB}$ binding was unaltered in the FA dentate nucleus and cerebellar hemisphere. ${ }^{3} \mathrm{H}-\mathrm{Flu}$ binding appeared to be slightly lowered in the inferior olivary and dentate nuclei yet was unchanged in the anterior and posterior cerebellar vermi and cerebellar hemisphere (Table 3). The binding of ${ }^{3} \mathrm{H}-\mathrm{DHA}$ was unaltered in the FA dentate nucleus, anterior and posterior cerebellar vermi, and cerebellar hemisphere while increased in the inferior olivary nucleus (Table 4).

\section{DISCUSSION}

The inferior olivary nucleus receives neuronal inputs from the spinal cord, brainstem, and cerebral cortex and is the major source of the climbing fibers which innervate the cerebellum (Noback and Demarest, 1972). Pathological studies revealed that this region is often severely atrophied in FA. In this study, both ${ }^{3} \mathrm{H}-\mathrm{QNB}$ and ${ }^{3} \mathrm{H}-\mathrm{DHA}$ binding were found to increase while ${ }^{3} \mathrm{H}-\mathrm{Flu}$ binding decreased in the FA inferior olive. The increased level of muscarinic cholinergic and $\beta$-adrenergic receptors suggests that these receptors are located on nondegenerated cell-types or noradrenergic neuronal activity might have occurred in the FA inferior olive. The lowered levels of ${ }^{3} \mathrm{H}-\mathrm{Flu}$ binding suggests that either benzodiazepine receptors are located on degenerated cells in the inferior olive or that these receptors have become desensitized.

The dentate nucleus is a deep cerebellar nucleus that is severely degenerated in FA. A major inhibitory pathway from the cerebellar cortex (via Purkinje fibers) innervated the dentate nucleus which sends output fibers to the ventral lateral and intralaminar thalamic nuclei as well as the red nucleus (Noback and Demarest, 1972). In the present study, benzodiazepine receptors were slightly depleted in FA dentate nucleus whereas muscarinic cholinergic and $\beta$ adrenergic receptors were unaltered. The results suggest that benzodiazepine receptors might be on degenerated cell-types in the FA dentate nucleus, while muscarinic cholinergic and $\beta$-adrenergic receptors are on non-degenerated cells.

Interestingly, ${ }^{3} \mathrm{H}-\mathrm{QNB}$ binding increased in both the FA anterior and posterior cerebellar vermi. Neither ${ }^{3} \mathrm{H}-$ Flu nor ${ }^{3} \mathrm{H}-\mathrm{DHA}$ binding were altered in these same regions. The increased level of muscarinic cholinergic receptors in the FA cerebellar vermi suggests that there may be a loss of and that decreases in cholinergic and/

\section{TABLE 4}

Regional ${ }^{3} \mathrm{H}-\mathrm{DHA}$ Binding in FA and Normal Brains

\begin{tabular}{l|ccccc}
\hline Brain Number & $\begin{array}{c}\text { Brain Region } \\
\text { Inferior } \\
\text { Olivary } \\
\text { Nucleus }\end{array}$ & $\begin{array}{c}\text { Dentate } \\
\text { Nucleus }\end{array}$ & $\begin{array}{c}\text { Ant. Cere. } \\
\text { Vermis }\end{array}$ & $\begin{array}{c}\text { Post. Cere. } \\
\text { Vermis }\end{array}$ & $\begin{array}{c}\text { Cere. } \\
\text { Hemisphere }\end{array}$ \\
\hline FA & & & & & \\
A-77-178 & 3.9 & 10.5 & 5.8 & 7.4 & 6.9 \\
A-77-218 & 20.2 & 16.8 & 11.3 & 10.0 & 17.0 \\
Average & 12.1 & 13.6 & 8.5 & 8.7 & 11.9 \\
Normal & & & & & \\
A-77-101 & - & 9.0 & 6.8 & 8.5 & 5.9 \\
A-77-71 & - & 14.4 & 7.5 & 9.2 & 9.2 \\
A-77-51 & 6.6 & - & 5.5 & 2.8 & 4.4 \\
A-75-149 & - & 10.4 & 6.7 & 5.8 & 14.7 \\
Average & 6.6 & 11.3 & 6.6 & 6.6 & 8.6 \\
\hline
\end{tabular}

The values are expressed as fmole of ${ }^{3} \mathrm{H}-\mathrm{DHA}$ bound per mg protein. The concentration of ${ }^{3} \mathrm{H}-\mathrm{DHA}$ used was $250 \mathrm{pM}$. 
cholinergic innervation in the cerebellar vermi of FA brains. Studies measuring the activity of choline acetyltransferase (a marker for cholinergic neurons) are currently in progress in order to determine if such a loss of cholinergic input occurs in the FA cexebellar vermis.

Neuropathological examinations revealed no gross pathological abnormalities in the FA cerebellar hemisphere. In accordance with these findings, no alterations in any of the neurotransmitter receptor levels were detected in this region of FA brains.

In the present study, only a limited number of FA brains were available for analysis. This small sample number prevented statistical comparisons and kinetic analysis of the FA and control groups. Therefore, the results of this study should be viewed with caution. However, this study does reveal trends in neurotransmitter receptor alterations in several FA brain regions. It is hoped that this initial information might promote further examination of the brain neurochemistry of FA.

\section{ACKNOWLEDGEMENTS}

We wish to thank A. Chen for his excellent technical assistance. Supported in part by U.S.P.H.S. grants and L'Association Canadienne de l'Ataxie de Friedreich. H.I.Y. is a recipient of a RSDA (MH-00095).

\section{REFERENCES}

BYLUND, D. B. and SNYDER, S. H . (1976) Beta adrenergic receptor binding in membrane preparations from mammalian brain. Mol. Pharm., 12, 568-580.

FRIEDREICH, N. (1861). Ueber degenerative atrophie der spinalen hinterstrange. Congress sitzungsbericht der Deutschen Aerzte and Naturforscher, Speier.

HUXTABLE, R., AZARI, J., REISINE, T. D., JOHNSON, P. C., YAMAMURA, H. I. and BARBEAU, A. (1978). Regional distribution of amino acids in Friedreich's ataxia brains. The Can. J. Neurol. Sci., this issue.

LOWRY, O. H., ROSEBROUGH, N. J., FARR, A. L. and RANDALL, R. J. (1951). Protein measurement with the Folin phenol reagent. J. Biol. Chem., 193, 265-275.
NOBACK, C. R. and DEMAREST, R. J. (1972). The Nervous System: Introduction and Review, McGraw-Hill, Inc., New York, pp. 121-131.

REISINE, T. D., FIELDS, J. Z., YAMAMURA, H. I., BIRD, E. D., SPOKES, E., SCHREINER, P., and ENNA, S. J. (1977). Neurotransmitter receptor alterations in Parkinson's disease. Life Sci., 21, 335-334.

SPETH, R. C., WASTEK, G. J., JOHNSON, P. C. and YAMAMURA, H. I. (1978). Benzodiazepine binding in human brain: Characterization using ${ }^{3} \mathrm{H}$-flunitrazepam. life Sci. 22, 859-866.

WINTROBE, M. M., THORN, G. W., ADAMS, R. D., BRAUNWALD, E., ISSELBACHER, $K$. J. and PETERDORF, R. G. (eds.) 1974. Harrison's Principles of Internal Medicine. McGraw-Hill Book Comp., New York, pp. 1740-1741.

YAMAMURA, H. I. and SNYDER, S. H. (1974). Muscarinic cholinergic binding in rat brain. Proc. Nat. Acad. Sci., 71, 1725-1729.

YAMAMURA, H. I. (1978). Neurotransmitter receptor alterations in Huntington's disease. In T. Melnechuk's (ed.), Cell Receptor Disorders, Western Behavioral Sciences Institute, La Jolla pp. 97-106. 